SAKAI SAMBAYAN — Jurnal Pengabdian kepada Masyarakat

\title{
BUDIDAYA UDANG VANAMEI SKALA SEMI INTENSIF DENGAN SALINITAS RENDAH DI KECAMATAN PASIR SAKTI KABUPATEN LAMPUNG TIMUR PROVINSI LAMPUNG
}

\author{
Supono $^{1^{*}}$, Eko Efendi ${ }^{2}$, Siti Hudaidah ${ }^{3}$, Deny Sapto Chondro Utomo ${ }^{3}$ \\ Jurusan Perikanan dan Kelautan Fakultas Pertanian Universitas Lampung \\ Penulis Korespondensi: supono_unila@yahoo.com
}

\begin{abstract}
Abstrak
Lampung Timur merupakan salah satu Kabupaten di Provinsi Lampung yang memiliki potensi besar dalam budidaya udang dan pernah mengalami kejayaan dalam budidaya udang. Saat ini budidaya udang dilakukan secara tradisional dengan produktivitas sangat rendah. Permasalahan yang muncul saat ini adalah kemampuan petambak terbatas dalam budidaya udang vaname, tata letak tambak yang kurang ideal, serta merebaknya penyakit. Berdasarkan kondisi tersebut, Tim Pengabdian kepada Masyarakat melakukan kegiatan penyuluhan dan pendampingan budidaya udang vaname skala semi intensif dengan salinitas rendah dengan mengambil lokasi Kecamatan Pasir Sakti Kabupaten Lampung Timur. Metode yang digunakan dalam kegiatan ini ada dua yaitu: Pelatihan dan pendampingan budidaya udang vaname. Tahap pertama berupa pelatihan yang meliputi: konstruksi kolam, teknik budidaya udang vaname dan manajemen kesehatan udang. Tahap pertama meliputi: konstruksi tambak, pemberian paket teknologi, serta pendampingan budidaya udang vaname skala intensif selama satu siklus. Hasil kegiatan menunjukkan bahwa kemampuan petambak yang menjadi sasaran kegiatan meningkat serta mampu melakukan budidaya udang vaname skala semi intensif dengan hasil yang sangat baik. Produktivitas tambak ukuran $2.000 \mathrm{~m}^{2}$ mampu mencapai $1.980 \mathrm{~kg}$.
\end{abstract}

Kata kunci : udang vaname, salinitas rendah, semi intensif, Pasir Sakti, Mina Sakti Mandiri

\section{Pendahuluan}

Provinsi Lampung mempunyai potensi yang sangat besar untuk dikembangkan sebagai produsen terbesar di Indonesia di sektor perikanan baik perikanan air payau (tambak udang dan bandeng) maupun perikanan laut (mariculture). Provinsi Lampung sejauh ini telah dikenal sebagai sentra produksi budidaya laut terutama ikan kerapu dan budidaya air payau terutama udang. Komoditi ini termasuk dalam kategori bahan makanan bernilai ekonomi tinggi. Kegiatan budidaya air payau (terutama udang) berkembang cukup pesat terutama yang dilakukan oleh perusahaanperusahan besar sampai menengah, baik yang dikelola oleh swasta nasional maupun asing. Selain itu beberapa unit kegiatan masyarakat juga mulai melakukan kegiatan usaha budidaya udang ini meskipun dengan skala kecil dengan teknologi yang masih sederhana.

Kabupaten Lampung Timur merupakan salah satu daerah otonom di Provinsi Lampung yang garis pantai sepanjang $200 \mathrm{~km}$ mempunyai potensi perikanan yang sangat besar. Saat ini potensi perikanan yang ada sekitar $22.548,05$ ha dengan pemanfaatan $15.909,29$ ha sementara potensi tambak rakyat sekitar 8.000 ha dengan pemanfaatan 4.728 ha. Kecamatan Pasir sakti merupakan salah satu sentra budidaya ikan dan udang yang dikelola secara tradisional baik melalui polikultur maupun monokultur. Sudah sejak dahulu daerah tersebut mengembangkan budidaya air payau terutama udang windu dan ikan bandeng.

Sampai saat ini budidaya udang yang dilakukan masyarakat di Kecamatan Pasir Sakti masih skala ekstensif/tradisional, belum ada input teknologi dan pakan buatan. Ketergantungan terhadap alam masih sangat besar sehingga hasil yang didapatkan tidak optimal. Aplikasi teknologi untuk meningkatkan daya dukung tambak belum diaplikasikan Berdasarkan survei, permasalahan yang dihadapi petambak udang adalah:

1. Kualitas air inlet yang jelek

2. Produktivitas tambak udang rendah $(<500 \mathrm{~kg} / \mathrm{ha})$

3. Keterbatasan pengetahuan dan dana sehingga tidak mampu 
mengoptimalkan lahan/tambak yang mereka miliki.

4. Keterbatasan pengetahuan petambak dalam budidaya udang vanamei skala semi intensif

Kontruksi tambak yang kurang baik serta manajemen budidaya yang angat sederhana menyebabkan kegagalan budidaya udang serta minimnya hasil yang diperoleh oleh tambak Kualitas air merupakan faktor utama pendukung keberhasilan budidaya udang, mengingat udang sangat sensitif terhadap kualitas air yang jelek Penyebab kedua dari minimnya penghasilan petambak adalah metode budidaya yang dilakukan saat ini masih tradisional yang mengandalkan produktivitas alami. Dalam satu hektar tambak hanya ditebar 30.000-50.000 ekor (3-5 ekor $/ \mathrm{m}^{2}$ ) dengan produktivitas sekitar 200-300 kg. Hal ini disebabkan minimnya pengetahuan petambak dalam budidaya udang secara semi intensif.

Berdasarkan permasalahan yang ada, solusi yang ditawarkan untuk mengatasi permasalahan tersebut adalah: budidaya udang vaname skala semi intsensif dengan salinitas rendah. Udang vaname atau udang putih merupakan udang introduksi yang berasal dari Perairan Amerika tengah (Wyban, 2007). Udang putih mulai dibudidayakan di Indonesia awal tahun 2000 (Kopot dan Taw, 2004) melalui beberapa perusahaan tambak udang di Lampung Produktivitas udang vanamei mencapai $>13.000$ $\mathrm{kg} / \mathrm{ha}$ (Supono, 2006), dengan tingkat kelulushidupan lebih dari $90 \%$ serta kepadatan penebaran sekitar 100 ekor $/ \mathrm{m}^{2}$ (skala intensif). Skala intensif disini yang dimaksudkan adalah budidaya udang dengan kepadatan 30-50 ekor/m2 dengan penambakan input pakan komesrsial dan peralatan. Sedangkan salinitas rendah yang digunakan berasal dari air tanah dengan salinitas 15 ppt (berdasarkan survey lokasi di Desa Purworejo, pasir Sakti). Menurut Wyban dan Sweeney (1991), udang vaname dapat hidup dengan baik pada salinitas rendah. Budidaya udang dengan salinitas rendah dapat menurunkan virulensi (tingkat keganasan) dari virus (Dayna et al., 2015). Beberapa penelitian juga menunjukkan bahwa udang vanamei mempunyai rentang salinitas yang lebar (5-35 ppt) (Jayasankar et al., 2009; Briggs et al., 2004). Keuntungan penggunaan air tanah dengan alinitas sekitar 15 ini antara lain kualitas air lebih baik dan baktrei pathogen lebih rendah. Skala semi intensif yang pengusul pilih dengan pertimbangan resiko kegagalan lebih kecil, modal lebih kecil, pengelolaan lebih mudah dibandingkan skala intensif tetapi mampu meningkatkan produktivitas kolam/tambak sekitar 10 kali dengan sistem tradisional.

\section{Materi dan Metode}

Kegiatan ini meliputi dua tahapan, yaitu pelatihan dan aplikasi paket teknologi. Pelatihan tentang budidaya udang vaname meliputi :

1. Pelatihan tentang konstruksi tambak dan persiapan tambak sebelum penebaran benih udang

2. Pelatihan tentang manajemen pakan budidaya vaname skala semi intensif;

3. Memberikan pelatihan tentang manajemen pemberian pakan dalam budidaya udang vanname skala semi intensif

4. Pelatihan tentang manajemen kesehatan udang vanamei

Aplikasi paket teknologi meliputi :

1. Kontruksi tambak (pendalaman, pemlastikan/lining dengan mulsa)

2. Paddle wheel/aerator untuk menambah kandungan oksigen terlarut dan pompa air untuk mengisi air

3. Manajemen budidaya udang vanamei skala semi intensif dengan salinitas rendah;

Selain pendampingan, Pokdakan juga diberi bantuan investasi operasional. Biaya investasi yang duberikan berupa: perbaikan tambak, plastik mulsa sebanyak 3 rol, kincir air (paddlewheel) 3 unit, 1 unit jenset $15 \mathrm{PK}$, pompa air, gudang pakan, rumah jaga, serta biaya operasional satu siklus.

\section{Hasil dan Ketercapaian Sasaran}

Kegiatan tahap pertama yang telah dilakukan adalah pelatihan budidaya udang vaname skala semi intensif denagn menggunakan salinitas rendah. Kegiatan dihadiri oleh 20 petambak yang tergabung dalam Kelompok pembudidaya ikan (Pokdakan) Mina Sakti Mandiri, Desa Purworejo, Kecamatan Pasir Sakti Kabupaten Lampung Timur, Provinsi Lampung. Materi pelatihan terdiri dari kontruksi tambak, prosedur budidaya udang vaname, manajemen pakan, dan manajemen kesehatan udang. Dari hasil evaluasi, rata-rata pengetahuan petambak dalam budidaya udang vaname meningkat dan petambak semakin termotivasi untuk melakukan budidaya udang 
vaname skala semi intensif. Tahap kedua dari kegiatan pengabdian adalah aplikasi budidaya udang vaname skala semi intensif dengan menggunakan air bersalinitas rendah. Langkah pertama yang dilakukan adalah konstruksi ulang tambak yang dijadikan percontohan karena tidak layak untuk budidaya udang vaname, baik mengenai kedalaman maupun perlengkapan yang lainnya. Luas tambak yang digunakan $2.000 \mathrm{~m}^{2}$. Tambak diperdalam sampai $1,5 \mathrm{~m}$ dan dilapisi dengan plastik mulsa pada bagian tanggul, dinding, sampai dasar kolam (3-4 m dari dinding) (Gambar 1). Tambak dilengkapi dengan kincir air (3 unit), lampu tambak, instalasi listrik, genset, gudang pakan, dan rumah jaga. Kondisi tambak sebelum dan setelah kegiatan pengabdian dapat dilihat pada Gambar 2.

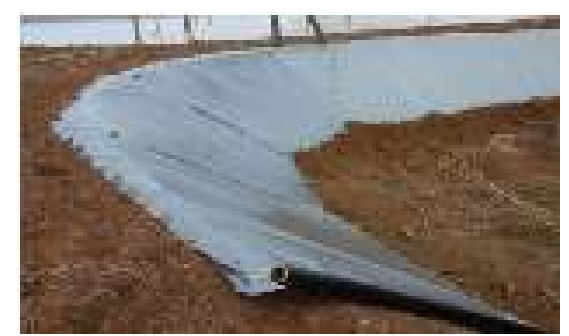

Gambar 1. Dinding tambak dilapisi plastik mulsa

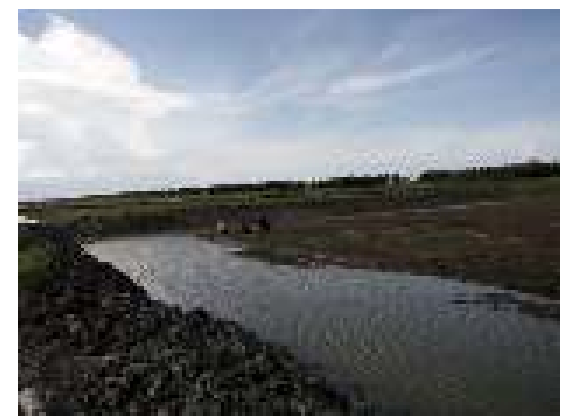

a. Kondisi tambak awal

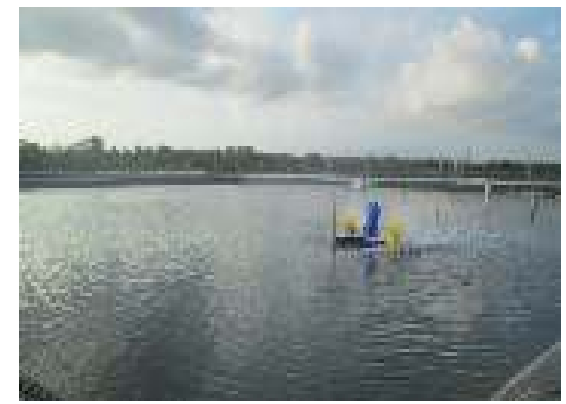

b. ambak setelah dikonstruksi ulang

Gambar 2. Kondisi tambak
Setelah persiapan tambak selesai, kegiatan berikutnya adalah proses budidaya udang vaname. Proses ini diawali dengan memasukaan air yang bersalinitas 10 ppt dari inlet, kemudian disterilisasi dari udang liar dan ikan. Setelah plankton terbentuk dengan stabil (warna hijau coklat, kecerahan 50-70 cm), dilakukan penebaran benih udang ukuran PL 10. Selama proses pembesaran dilakukan penambahan air tanah yang bersalinitas $<10$ ppt sampai sekitar 5 ppt pada akhir budidaya Pemeliharaan udang dilakukan sampai umur 110 hari. Panen udang dilakukan dengan metode, yaitu panen parsial dan total. Panen parsial (sebagian) dilakukan pada umur 60 hari dan 72 hari yang bertujuan untuk mengurangi populasi udang agar pertumbuhan lebih cepat. Sedangkan panen akhir/total dilakukan pada umur 110 hari. Hasil panen budidaya udang vaname skala intensif dapat dilihat pada Tabel 1.

Tabel 1. Hasil panen budidaya udang skala semi intensif

\begin{tabular}{|c|c|c|}
\hline No & Variabel & Keterangan \\
\hline 1 & Luas kolam & $2.000 \mathrm{~m}^{2}$ \\
\hline 2 & Jumlah benur & 140.000 ekor \\
\hline 3 & Kepadatan & 70 ekor $/ \mathrm{m}^{2}$ \\
\hline 4 & $\begin{array}{l}\text { Tingkat } \\
\text { kelulushidupan }\end{array}$ & $85 \%$ \\
\hline 5 & $\begin{array}{l}\text { Panen parsial I } \\
(\text { size } 97)\end{array}$ & $\begin{array}{c}310 \quad \mathrm{~kg} \\
\text { (30.097 ekor) }\end{array}$ \\
\hline 6 & $\begin{array}{l}\text { Panen Parsial II } \\
(\text { size } 76)\end{array}$ & $\begin{array}{c}515 \quad \mathrm{~kg} \\
\text { (39.313 ekor) }\end{array}$ \\
\hline 7 & $\begin{array}{l}\text { Panen akhir (size } \\
42 \text { ) }\end{array}$ & $1.180 \mathrm{~kg}$ \\
\hline 8 & Total panen & $2.005 \mathrm{~kg}$ \\
\hline 9 & Konversi pakan & 1,5 \\
\hline 10 & Umur panen & 110 hari \\
\hline
\end{tabular}

Total biaya produksi selama satu siklus budidaya mencapai Rp. 86.830 .000 dengan pendapatan total Rp. 159.204.000 sehingga keuntungan yang diperoleh Rp. 72.374.000. Analisis ekonomi budidaya udang vaname skala intensif dengan salinitas rendah terdapat pada Tabel 2.

Dari hasil evaluasi awal diketahui bahwa sebelum program pengabdian ini dilaksanakan, tingkat pengetahuan sebagian besar petambak yang tergabung dalam Pokdakan Mina Sakti Mandiri masih rendah dalam budidaya vaname, terutama dalam pembuatan konstruksi kolam yang benar, persiapan kolam dan proses budidaya udang vaname. Hal ini menunjukkan bahwa sebelum dilakukan pelatihan sebagian besar petambak udang di Kecamatan Pasir Sakti tidak memahami 
teknologi budidaya udang vaname secara semi intensif.

Tabel 2. Analsis ekonomi budidaya udang skala semi intensif.

\begin{tabular}{|c|c|c|c|c|}
\hline No & Keterangan & Jumlah & $\begin{array}{c}\text { Harga } \\
\text { (Rp) }\end{array}$ & Total (Rp) \\
\hline & Biaya Produksi & & & \\
\hline 1 & benih udang & 120.000 & 45 & 5.400 .000 \\
\hline 2 & pakan & 3.025 & 14.000 & 42.350 .000 \\
\hline 3 & obat-obatan & & & 1.000 .000 \\
\hline 4 & BBM & $\begin{array}{r}2.600 \\
4\end{array}$ & 5.800 & 15.080 .000 \\
\hline 5 & tenaga kerja & $\begin{array}{r}\text { bulan/or } \\
\mathrm{g}\end{array}$ & $\begin{array}{r}1.500 .00 \\
0 \\
1.000 .00\end{array}$ & 6.000 .000 \\
\hline 6 & Insentif & 2.000 & 0 & 2.000 .000 \\
\hline 7 & Lain-lain & & & 5.000 .000 \\
\hline 8 & Penyusutan & & & 10.000 .000 \\
\hline & Jumlah & & & 86.830 .000 \\
\hline & $\begin{aligned} & \text { Hasil panen } \\
&- \text { Parsi } \\
& \text { al I } \\
&- \text { Parsi } \\
& \text { al II } \\
&- \text { Pane } \\
& \text { n } \\
& \text { akhir } \\
& \\
& \text { Total }\end{aligned}$ & $\begin{array}{l}310 \mathrm{~kg} \\
515 \mathrm{~kg}\end{array}$ & & $\begin{array}{r}13.350 .000 \\
21.500 .000 \\
124.354 .00 \\
0 \\
0 \\
159.204 .00 \\
0\end{array}$ \\
\hline & keuntungan & & & 72.374.000 \\
\hline & $\mathrm{B} / \mathrm{C}$ ratio & & & 0,83 \\
\hline & $\mathrm{R} / \mathrm{C}$ ratio & & & 1,83 \\
\hline
\end{tabular}

Tingkat pengetahuan para petambak di Desa Purworejo Kec. Pasir Sakti, Kab. Lampung Timur tersebut dalam membudidayakan udang vaname dengan skala intensif dengan salinitas rendah masih sangat rendah karena teknologi yang mereka terapkan dalam budidaya udang hanya berdasarkan pengalaman yang diwariskan secara turun-temurun (tradisional), sehingga hasilnya kurang maksimal. Antusiasme petambak dalam mengikuti pelatihan baik di dalam ruangan maupun kelas sangat tinggi sehingga memudahkan Tim Pelaksana dalam menyampaikan materi pelatihan.

Pemahaman tentang konsep budidaya udang vaname serta praktek di lapangan telah dikuasai oleh anggota kelompok. Beberapa teknik yang telah dikuasi oleh petambak meliputi : persiapan kolam, persiapan air, penebaran benih

Vol 5 No 2 Juli 2021 udang, manajemen kualitas air, manajemen penyakit, manajemen pemberian pakan, serta monitoring pertumbuhan udang. Aplikasi teknologi dalam budidaya udang telah diterapkan oleh petambak hal ini bisa dilihat dari keberhasilan memelihara udang sampai sampai umur panen 110 hari. Panen udang dilakukan sebanyak 3 kali yaitu panen parsial I pada umur 60 hari ( berat udang 10 g), parsial II pada umur 72 hari (berat udang $15 \mathrm{~g}$ ) dan panen akhir atau total pada umur 110 hari (berat udang 25-26 g).

Dampak yang sudah terlihat dari kegiatan pengabdian di kecamatan Pasir Sakti Kabupaten Lampung Timur ini antara lain :

1. Kelompok pembudidaya ikan Mina Sakti mandiri telah berhasil menerapkan budidaya udang vaname skala semi intensif dengan salinitas rendah

2. Meningkatnya produktivitas tambak serta pendapatan petambak (keuntungan per siklus 50-70 juta)

3. Penyediaan lapangan kerja baru terdiri dari :
a. anak kolam : 1 orang
b. Tenaga panen : 6 orang
c. Transportasi : 2 orang

4. Kegiatan budidaya udang yang dilakukan Pokdakan Mina sakti Mandiri telah menjadi contoh bagi petambak lainnya sehingga sekarang mulai berkembang budidaya udang vaname skala semi intensif, baik di kecamatan pasir sakti maupun Kecamatan di sekitarnya (multiple effect).

5. Mulai munculnya Pembeli udang tingkat petani yang akan menyuplai Cold storage yang ada di Jakarta

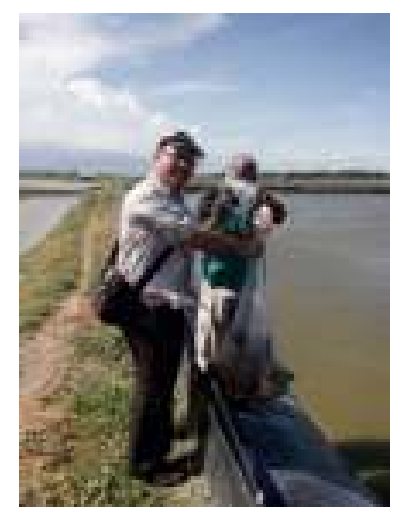

Gambar 3. Panen udang vaname 


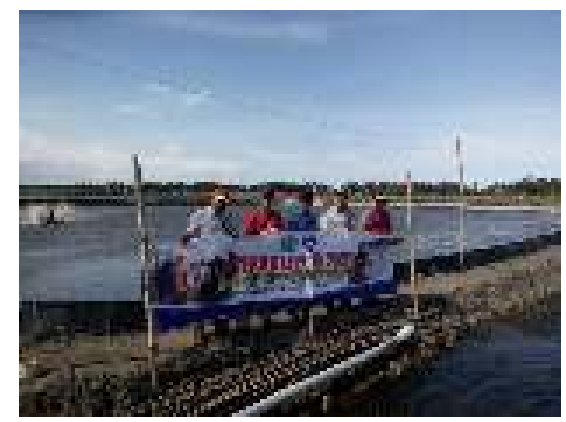

Gambar 4. Kegitan monitoring dan evaluasi

\section{Kesimpulan}

Melalui program pengabdian kepada masyarakat ini petambak udang pokdakan Mina Sakti Mandiri telah menguasai teknik budidaya udang vaname skala semi intensif dengan salinitas rendah. Petambak telah memahami proses budidaya udang mulai dari konstruksi kolam, persiapan air, penebaran benih udang, manajemen budidaya udang hingga monitoring pertumbuhan udang. Petambak udang pokdakan Mina Sakti Mandiri telah berhasil membudidayakan udang vaname dengan sistem semi intensif dengan salinitas rendah dengan hasil yang sangat memuaskan. Hasil panen total satu siklus untuk tambak ukuran $2.000 \mathrm{~m}^{2}$ mencapai $1.980 \mathrm{~kg}$ dengan berat udang rata-rata $25 \mathrm{~g}$. Keberhasilan budidaya udang putih skala semi intensif ini telah menjadi multiple effect bagi kegiatan budidaya udang di Kecamatan Pasir Sakti Kabupaten Lampung Timur.

\section{Ucapan Terima Kasih}

Kami, Tim pengabdian kepada Masyarakat, mengucapkan banyak terima kasih kepada Lipi yang telah membiayai kegiatan ini melalui program Iptekda Lipi sehingga kegiatan dapat berjalan dengan lancar dan memberikan dampak positif bagi masyarakat di lokasi kegiatan.

\section{Daftar Pustaka}

Briggs M., S. F. Smith, R. Subasinghe, and M. Phillips. 2004. Introductions and movement of Penaeus vannamei and Penaeus stylirostris in Asia and the Pacific. RAP publication. 32 hal

Davis, D. A., Saoud, I. P., McGraw, W. J., Rouse, D. B., 2002. Considerations for Litopenaeus vannamei reared in inland low salinity waters. In: Cruz-Suárez, L. E., Ricque-Marie, D., Tapia-Salazar, M., Gaxiola-Cortés, M. G., Simoes, N. (Eds.). Avances en Nutrición Acuícola VI. Memorias del VI Simposium Internacional de Nutrición Acuícola. 3 al 6 de
Septiembre del 2002. Cancún, Quintana Roo, México

Dayma,P., I.H. Raval, N. Joshi, N.P. Pate, S. Haldar, dan K.H. Mody.2015. Influenceof low salinity stress on virulence and biofilm formation potential in Vibrio alginolyticus, isolated from the Gulf of Khambhat, Gujarat India. Aquatic Living Resources, 28: 99-109

Jayasankar, V., S. Jasmani , T. Nomura, S. Nohara, D.T.T. Huong, dan M.N. Wilder. 2009. Low salinity rearing of the pacific white shrimp litopenaeus vannamei: acclimation, survival and growth of postlarvae and juveniles. JARQ 43 (4), 345-350

Kopot, R. and N. Taw. 2002. Efficiency of Pacific White Shrimp, Current Issues in Indonesia. Global Aquaculture Advocate: 40-41

Supono. 2006. Produktivitas udang putih pada tambak intensif di Tulang Bawang Lampung. Jurnal Saintek Perikanan 2 (1) : 48-53

Wyban, J.A, and J.N. Sweeney. 1991. Intensive shrimp production technology. The Ocean Institute Honolulu, Hawai. 158 hal.

Wyban, J.A. 2007. Domestication of Pacific White Shrimp Revolutionizes Aquaculture. Global Aquaculture AdvocateJuly/August : 42-44 